\title{
Sustainable Finance in Sustainable Health Care System
}

\author{
Anastasios Sepetis \\ University of West Attica, Athens, Greece \\ Email: tsepet@yahoo.com
}

How to cite this paper: Sepetis, A. (2020) Sustainable Finance in Sustainable Health Care System. Open Journal of Business and Management, 8, 262-281.

https://doi.org/10.4236/ojbm.2020.81016

Received: November 26, 2019

Accepted: December 28, 2019

Published: December 31, 2019

Copyright $\odot 2020$ by author(s) and Scientific Research Publishing Inc. This work is licensed under the Creative Commons Attribution International License (CC BY 4.0).

http://creativecommons.org/licenses/by/4.0/

\begin{abstract}
Nowadays the WHO and the EU health care system is influenced by Sustainable Development Goals. The implementation of public or voluntarily environmental, social and corporate governance (ESG) policies in hospitals causes extra costs and revenue to the health care system. The financial risk of sustainable hospitals and of the sustainable health care system, as well as the capabilities and the suggestions for the best possible financial analysis assessment, consist a new research field. This paper will investigate this new research field of sustainable health care and sustainable finance and will add scientific knowledge and methodological implementation to financial assessment analysis tools to those entities responsible for the implementation of sustainable health care system policies and the capital market investors, in order to take the best possible decisions.
\end{abstract}

\section{Keywords}

Sustainable Finance, Sustainable Health Care, Sustainable Hospital, Environmental, Social, and Governance (ESG) Assessment, Long-Term Paradigm, Sustainable Investments, Systems Perspective, Corporate Social Responsibility

\section{Introduction}

Health care system is considered among the largest industries worldwide. The public expenditure on health and long-term care in Organization for Economic Co-operation and Development (OECD) countries is set to increase from around $6 \%$ of GDP today to almost $9 \%$ of GDP in 2030 and as much as $14 \%$ by 2060. At the EU, healthcare sector accounts for $10 \%$ of gross domestic product (GDP), $15 \%$ of public expenditure and $8 \%$ of the EU's workforce [1]. In the same era the WHO suggests that the 2030 agenda for Sustainable Development 
Goals is an opportunity for governments and international community to renew their commitment to improving health as a central component of development. The accompanying 17 sustainable development goals (SDGs) define the priority areas of action. The Goal 3 (to ensure healthy lives and promote wellbeing for all at all ages), with Target 3.8 on universal health coverage (UHC), emphasizes the importance of all people and communities having access to quality health services without risking financial hardship [2] [3].

In the question of how to finance the sustainable development goals, in the last years new sustainable finance stakeholders have developed. By leveraging the UN's role, UNEP FI accelerates sustainable finance. The United Nations Environment Programme Finance Initiative (UNEP FI) is a partnership between UNEP and the global financial sector to mobilize private sector finance for sustainable development. UNEP FI works with more than 300 members-banks, insurers, and investors-and over 100 supporting institutions-to help create a financial sector that serves people and planet while delivering positive impacts. UNEP FI supports global finance sector principles to catalyze integration of sustainability into financial market practice. These frameworks establish the norms for sustainable finance, providing the basis for standard-setting and helping to ensure that private finance fulfils its potential role in contributing to achieving the 2030 Agenda for Sustainable Development and Paris Agreement on Climate Change agreed by governments around the world in 2015 [4]. The EU Commission defines "Sustainable finance" as the process of taking due account of environmental and social considerations when making investment decisions, leading to increased investment in longer-term and sustainable activities. More specifically, environmental considerations are referred to climate change mitigation and adaptation, as well as to the environment more broadly and to the related risks (e.g. natural disasters). Social considerations may refer to issues of inequality, inclusiveness, labor relations, investment in human capital and communities. The governance of public and private institutions, including management structures, employee relations and executive remuneration, plays a fundamental role in ensuring the inclusion of social and environmental considerations in the decision-making process. All three components-environmental, social and governance (ESG)-are integral parts of sustainable economic development and finance. Recently, the European Commission established the EU High-Level Group on Sustainable Finance (HLEG) for promoting Sustainable Development Goals (including sustainable health care system goals) to help develop an overarching and comprehensive EU roadmap on sustainable finance. In May 2018, the EU Commission adopted a package of measures implementing several key actions announced in its action plan on sustainable finance report. The Report argues that sustainable finance is about two urgent imperatives: 1) improving the contribution of finance to sustainable and inclusive growth by funding society's long-term needs; 2) strengthening financial stability by incorporating environmental, social and governance (ESG) factors into investment decision-making $[5]$. 
The benefits of sustainable development goals and sustainable finance in the health care system are more important than ever before. For hospitals' CEOs the sustainable finance incorporating environmental, social and governance (ESG) factors into investment decision-making must be ranked as their top concern. In the current health care system environmental, social and governance (ESG) efforts must be financially viable to succeed long term. Hospitals and health care systems are already saving resources by adopting (ESG) evaluation measures. To mitigate financial risk, finance leaders emphasized the need to understand the direct and indirect environmental, social and governance costs of running their organization in the short-term, and how these costs intersect with long-term business strategy [6]. Specifically, environmental, social and governance components involve evaluating the financial effectiveness and longitudinal value of current hospitals operations.

For the financial stakeholder of firms and the health care system have been a source of considerable confusion the fact that ESG risk of health care systems and hospitals itself is interpreted differently in different types of financial institutions [7] [8]. Commercial banks are primarily concerned with environmental or social and governance (ESG) factors of hospitals affecting the borrower's creditworthiness and avoiding additional ESG costs. Investment banks are turning their attention to this parameter, plus all the ESG effects of hospitals that have an impact on the demand or supply of business debt securities. Insurers are only concerned about risk taking for the probability of accidental environmental or social events of hospitals and seek to avoid, by internal procedures, the risk weighting and uncertainty that their client's environmental or insurance claims impart by transferring them to the market. The institutional investor or venture and pension fund manager can account for a wide range of environmental and social threats of hospitals, many of which are qualitative rather than quantitative. When listening to the term environmental and social risk the commercial banker tends to associate it with the balance sheet data (downgraded territory - reputation and customer - difficulty in repaying the loan), the insurer with environmental accidents. Institutional investors (pension funds, mutual funds) and capital investment managers are generally more interested in what environmental or social and governance regulations entail in business processes and less in the making of profitable investment decisions.

However, the sustainable or social or environmental responsible investing strategies of hospitals should be highlighted as investment opportunities in healthcare system. The frameworks UNEP FI has established or co-created include: 1) Principles for Responsible Banking (PRB) launched with more than 130 banks collectively holding USD 47 trillion in assets, or one third of the global banking sector, on 22 September 2019. 2) Principles for Sustainable Insurance (PSI), established 2012 by UNEP FI and today applied by one-quarter of the world's insurers (25\% of world premium). 3) Principles for Responsible Investment (PRI), established in 2006 by UNEP FI and the UN Global Compact, now applied by half the world's institutional investors (USD 83 trillion). UNEP FI al- 
so supports the Sustainable Stock Exchanges Initiative (SSEI), launched in 2012 with UNCTAD, UN Global Compact, and the PRI. Today this involves 90 stock exchanges accounting for almost all publicly-listed capital markets [4]. In the EU the Eurosif recently updated its classification for sustainable investment strategies in its prominent European Socially Responsible Investment (SRI) Study. This classification refers to seven main categories: sustainability themed investment funds, best-in-class investment selection, norms-based screening, and exclusion of holdings from investment universe, integration of ESG factors in financial analysis, engagement and voting on sustainability matters, and impact investing [9]. The EU is committed to transforming Europe's economy into a greener, social and more resilient and circular system. The European Fund for Strategic Investments (EFSI) were channeled into energy, environment and resource efficiency projects and social infrastructure. The EFSI 2.0 extends the fund until 2020 and raises investment targets to EUR 500 billion, with at least $40 \%$ of EFSI financing for infrastructure and innovation to support climate and social action projects (EU Commission, 2018) [10]. According to the US SIF Foundation's 2018 Report, only on US Sustainable, Responsible and Impact Investing Trends, as of year-end 2017, more than one out of every four dollars under professional management in the United States are invested in SRI strategies [10]. The Hospitals and health care systems will face the transformation of global and Europe's economy and SRI strategies in the capital market, therefore, changes should be made in the health care system and transform from a volume-based market to a value-based market.

Today, sustainable development goals and sustainable health care should be funded, but national health care finance is obviously not sufficient to meet these investment needs yet. Consequently, the public and private sustainable financial sector has an important role to play in filling this investment gap. Mobilizing public and private investors to finance sustainable projects on health care system should be important. Therefore, achieving a tangible financial analysis assessment model for sustainable hospitals and sustainable health care system that will be proper for new sustainable finance market is essential.

\section{Estimate Sustainable Environmental, Social and Governance Costs as Financial Risk in the Health Care System}

During the past decade, environmental and social risks have progressively dominated the global financial risks. According to the World Economic Forum's report in 2019 for the third consecutive year, three of the top five global risks, in terms of both likelihood and impact, are environmental and all three are associated with climate change [11]. Also, in this era the climate change and the environmental and social risk are serious public health threats to people in all countries. Human activities, in particular the burning of fossil fuels, have been identified as key drivers of climate changes observed since the mid-twentieth century. The effects of these activities are altering the environment on which we 
depend, and threaten our collective future through very serious effects on human health [12]. Future health outcomes depend on multiple factors beyond the level of greenhouse gas emissions and resulting warming [13]. The contribution of environmental and social factors to the burden of disease will be magnified and increased with the growing health-related impacts. These include shifting patterns of disease, water and food insecurity, vulnerable shelter and human settlements, environmental refugees, extreme climate events, heat related illness and population migration. The magnitude of these multiple looming crises led The Lancet to declare in 2009 that "Climate change is the biggest global health threat of the 21st century," and will "put the lives and wellbeing of billions of people at increased risk" [14]. Regarding Sustainable Development Goals (SDG), at Lancer research paper in 2016, it is referred that moderate improvements have been observed for indicators, such as the incidence of HIV and tuberculosis, minimal changes in hepatitis B incidence, whereas excess child weight has increased considerably [15]. In the resent paper in 2017 "The Lancet Global Health represents a milestone in the implementation of this ambitious SDG agenda" [16]. It is estimated that an additional $\$ 274$ billion spending on health is needed per year by 2030 to make progress towards the SDG 3 targets (progress scenario), whereas US $\$ 371$ billion would be needed to reach health system targets in the ambitious scenario. Another question that arises is "if the sustainable development goal target for financial risk protection in health is realistic?" investigated by Verguet et al in 2017. In that project they established an empirical basis for the measurement, tracking and setting of appropriate SDG targets for financial risk protection (FRP) - prevention of medical impoverishment-based on what might be possible to achieve in the future. They concluded that historical trends of catastrophic health expenditure rates can help define post-2015 targets for FRP. The projected achievements suggest that elimination of medical impoverishment would not be achieved by 2040 [17]. Another paper in Lancer by Fryatt, and Bhuwanee, mentions that it is now known how much investment is required to reach the health SDGs, and where these investments should be made. The health SDGs are ambitious, but it is starting to become clear that, where consistent, sustained political commitment exists, they are within reach [18].

Until recently, there have been limited metrics to gauge the scale of the issues, but emerging data confirm the significance of the health sector's environmental and social impacts. The National Health Service (NHS) in England in 2010 has calculated its carbon footprint at more than 18 million tons of $\mathrm{CO} 2$ each year $25 \%$ of total public sector emissions also the NHS in England consumes 39 billion liters of water and produces 26 billion liters of sewage each year [19]. In the US, healthcare sector accounts for $17.9 \%$ of GDP (in 2009), consuming billions of $\mathrm{KW}$ and employing millions people, but it is producing 5.9 million tons of wastes annually and $8 \%$ of total US carbon dioxide emissions [20]. According to U.S. Energy Information Administration states that large hospitals make up just 2 percent of commercial floor space in the United States but use about 5.5 percent of energy delivered to the commercial sector (U.S. Energy Information 
Administration, 2012). In China, healthcare construction spending exceeds US $\$ 10$ billion a year, and is growing by $20 \%$ annually, consuming significant amounts of natural resources (China healthcare construction). According to Komilis, definitions of health care wastes vary a lot among the countries that cause a wide range of reported health care waste generation rates - from hundred grams and up to $6 \mathrm{~kg}$ per bed per day [21]. There are many more examples. The environmental health impact of hospitals should come as no surprise given the health sector's huge economic clout.

The ANH (Alliance for Natural Health) first defined sustainable healthcare for its readers in the journal Nutrition Practitioner in 2006. "A complex system of interacting approaches to the restoration, management and optimization of human health that has an ecological base, that is environmentally, economically and socially viable indefinitely, that functions harmoniously both with the human body and the non-human environment, and which does not result in unfair or disproportionate impacts on any significant contributory element of the healthcare system" [22]. Green hospital can be defined in a number of ways. Office of the Federal Environmental Executive defines a green or sustainable building as "the practice of increasing the efficiency with which buildings and their sites use energy, water, and materials, and reducing building impacts on human health and the environment, through better siting, design, construction, operation, maintenance, and removal-the complete building life cycle" [23]. According to Health Care Without Harm "A green and healthy hospital is one that promotes public health by continuously reducing its environmental impact and ultimately eliminating its contribution to the burden of disease. A green and healthy hospital recognizes the connection between human health and the environment and demonstrates understanding through its governance, strategy and operations. It connects local needs with environmental action and practices primary prevention by actively engaging in efforts to foster community environmental health, health equity and green economy" [24]. In order sustainable hospitals and sustainable health care facilities to make progress in sustainable finance areas, it's important to take a practical, feasible approach that aligns with budget and finance considerations. According to Weisz, in order to define "sustainable hospital", additional criteria should be introduced: 1) contribution to the preservation of nature by limiting resource use and other environmental pressures, 2) reduction of costs to the national economy, and 3) minimization of social burdens within and outside the hospital. "Sustainable decisions" should take all these dimensions into account together by evaluating different options also in terms of their side effects and long-term consequences [25].

To establish a sustainable effective healthcare system over the long term and to make sustainable hospital affordable for everyone, we also need technological and financial innovations that both improve the quality of medical care and help save money. The financial risk protection is a core component of sustainable finance and should therefore be considered a key dimension of sustainable health benefits package. 


\section{The Financial Management Risk of Environmental, Social Governance into Sustainable Hospitals and Sustainable Health Care Systems}

The effects of financial management risk from public and voluntary sustainable development investment on the operation of hospitals and the healthcare systems that will increase or decrease environmental, social corporate governance costs or revenue are initially distinguished from those directly and indirectly. Direct effects are considered to influence the individual's health decisions. For instance direct effects are the purchase of special medical hazard waste incinerators, while indirect effects are discernible, such as the reduction of energy consumption [26] [27]. The second distinction is in the effects that can be calculated monetary (quantitative effects) and in those which are not feasible or numerical (any qualitative unit of measurement), that is, qualitative one's effects [28] [29] [30] [31]. A third, equally important, distinction is microeconomic and macroeconomic impact of environmental, social and governance policies. Microeconomic impacts are mainly related to the functioning of the individual hospitals, while macroeconomic analysis shows the impact on the health care sector or the entire economy [32] [33].

Moreover, hospitals' CEOs often pay attention to the environmental, social or governance indicators, as factors that influence ESG financial risk. Environmental factors are about a hospitals' impact on the environment. They are based on the premise that business activities have the potential to create environmental risks for ecosystems, water, air and human health. As a result, positive outcomes, such as decreasing costs and improving profitability due to better energy efficiency are expected. Reputational risks will also reduce. Social factors have to do with the way businesses treat and value people. In other words, it is about the impact that hospitals can have on their employees and on society. As a consequence, business productivity and employees' moral increases, turnover decreases, and reputational risks are better managed. It also gets easier to work without social pressure from stakeholders, as there's social license to operate. The governance factors focus on corporate policies and how hospitals are governed. It is about making the responsibilities, rights, and expectations of stakeholders clear, so that interests are met and a consensus on a hospital's long-term strategy is achieved [34] [35] [36].

In the financial stakeholders' side, relevant literature review identifies five key ways, in which ESG business risk and business opportunities that also include hospitals' business operation can be transferred as financial risk or value to financial stakeholders [37] [38] [39]. These are: 1) increased credit and insurance risk (Credit and Insurance Risk): The imposition of fines, the evolution of environmental or social standards to the most stringent, environmental accidents, ongoing state surveillance, social demand and consumer preferences for healthy productive activities and green products create additional and usually unforeseen costs that make repayment of loans or insurance fees impossible, 2) With 
Security Impairment Risk: The possible deterioration of territorial ownership in an area and the consequent intensification of environmental regulations are causing an immediate decrease in the value of the guarantee for fixed assets affected by these developments, 3) By converting credit or insurance risk into direct legal liability (Direct Liability Risk). This is the case where, by special regulation, the common law allows the state to impose on banks or insurance directly responsible for environmental disasters, which are caused or related to their customers (borrowers). This is a policy that is already widely followed in America and Great Britain, 4) Increasing the Risk of Loss of Reputation and Brand (Brand Name Risk): In addition to the environmental and social risk of banks and insurance, whoever is concerned with non-repayment of loans or insurance fees and the legal liability of lenders, concerns about the risk of reputation act as guides in making a bank or insurance decision, 5) Third Party Liability: The banks and insurance companies under national law are not only responsible for hospitals' environmental disasters, but in every environmental accident hospitals are responsible for restoring the assets of third parties (for all those who have suffered injury).

Hospitals' ESG value and its business value are reflected in each other and despite the distortions that the market entail they are mutually interdependent. There is no perfectly acceptable way of calculating these values, but as it is explained in the following chapter, there are several factors that allow us to reliably predict their course. Our financial analysis method process begins with fundamental and quantitative research in conjunction with rigorous impact evaluation and scoring to better assess risk/return dynamics of the specific investment. Now there is the time to recognize environmental, social and governance (ESG) factors in the health care system and hospitals can impact the ESG performance of health care public and private investment portfolios.

\section{The Environmental, Social and Corporate Governance (ESG) Financial Analysis Assessment in the Sustainable Health Care System and Sustainable Hospitals}

Sustainable finance theory and hospital ESG business practice will soon become part of investment policies to describe the return on investment portfolios and funds. ESG's financial analysis can also provide information on long-term prospects. Investors can find new market opportunities with hospitals that place ESG management at the core of their business value. However, doubts have arisen as to whether financial analysts really know what to do with ESG-related hospital information [40]. This information is not very standardized and harmonized, which makes it even more difficult to interpret for investment decision-makers [41]. The question today is how environmental, social and intergovernmental (ESG) criteria can be assessed in a healthcare system and in hospitals with financial analysis methods. According to Orlitzky, the difficulty of distinguishing between significant and unimportant sustainability measures results in many unintended deliberate consequences [42]. 
In the context of International Accounting Standards -I.A.S.s, numerous efforts have been made to record the environmental impacts on the business operation of businesses and, by extension, on hospitals. I.A.S.s can incorporate environmental information into international accounting standardization by separating relevant hospitals accounts [43] [44]. Also the Sustainability Accounting Standards Board (SASB's) use of the term "sustainability", as it refers to corporate activities that maintain or enhance the ability of the hospitals to create value over the long term. The Sustainability Accounting Standards Board (SASB) also refers to sustainable hospitals as "ESG" (environmental, social, and governance), though traditional corporate governance issues, such as board composition are not included within the scope of the SASB's standards-setting activities [45].

The ESG financial analysis assessment is a term that encompasses investments that aim to have positive returns and a long-term impact on sustainable health care system. As it identifies investments' potential risks and opportunities beyond technical valuations, ESG in hospitals has the potential to enhance the traditional financial analysis mostly because these hospitals are more likely to outperform in the long-run when compared to the competition. Researchers Senay and Landrigan [46] published the first assessment of sustainability reporting in the USA. If mention of sustainability terms on the main corporate website is a proxy for corporate commitment to these activities, then health care corporations lag; only 2 of 8 (25\%) of Fortune 500 companies; 1 of 3 (33\%) of S \& P 500 companies, 1 of 8 (13\%) of Forbes 100 Largest Charities, and 5 of $14(36 \%)$ of top state employers mentioned sustainability or CSR terms on their main websites. Furthermore, $77 \%$ of all S \& P 500 and $52 \%$ of all Fortune 500 companies disclosed carbon emission information to the Carbon Disclosure Project, but only 1 of 8 (13\%) of Fortune 500 health care companies, 1 of 8 (13\%) of Forbes 100 Largest Charities, 2 of 14 (14\%) of the largest state employer health care systems, and no S \& P 500 health care companies mentioned carbon emissions in corporate material. While, overall performance in sustainability reporting is poor compared with other economic sectors, there are indications that these activities have some importance to health care corporations. A greater number of health care corporations were found to mention basic sustainability information when searched via Google: 2 of $3(66 \%)$ of S \& P 500, 5 of 8 (63\%) of Fortune 500 , and 8 of 14 (64\%) of the largest state employer HCOs. Most also included at least 1 metric, which provides some evidence of commitment to sustainability; however, without publishing a CSR report or including mention of these efforts on the main website, it is difficult to determine to what degree HCOs truly value and pursue these activities.

\subsection{The KPI s Factor for Hospitals ESG Evaluation}

Nowadays, public and private investors are using more often their investing power in order to establish their own social, environmental and governance moral attitude in the healthcare market. This way of thinking is based on the assumption that hospitals under the suitable instigation can gain profit by contri- 
buting positively to the improvement of social and environmental living conditions. For sustainable finance in hospitals and the health care system, the measuring impact is the key. The European Federation of Financial Analysts Societies (EFFAS) says that companies including hospitals and Health care organizations should point out how ESG is important for their businesses and share how they integrate ESG factors within their ESG strategy. They suggest that organizations develop and disclose their strategy to enhance transparency about risk exposure [47]. The UN Principles for Responsible Investment provide a voluntary ESG framework for companies (page 75 note in healthcare sector) and funds, from which investors can make informed investment decisions that relate to sustainability and governance practices in the health care sector [48]. That paper suggests presenting ESG data in the hospitals annual report, on the corporate website and in meetings with investors. Along with these main topics that cover all health care systems and sectors, they've also identified specific ESG criteria for key performance indicators (KPIs) factors (Table 1).

Table 1. ESG Hospitals KPIs factors: The Key Performance Indicators (KPI) are customized to each sector of the Environmental, Social and Governance in the hospitals for that reason successful sustainable healthcare systems are those that take a holistic approach that goes beyond the provision of medicine, manage their ESG footprint and make facilities more efficient.

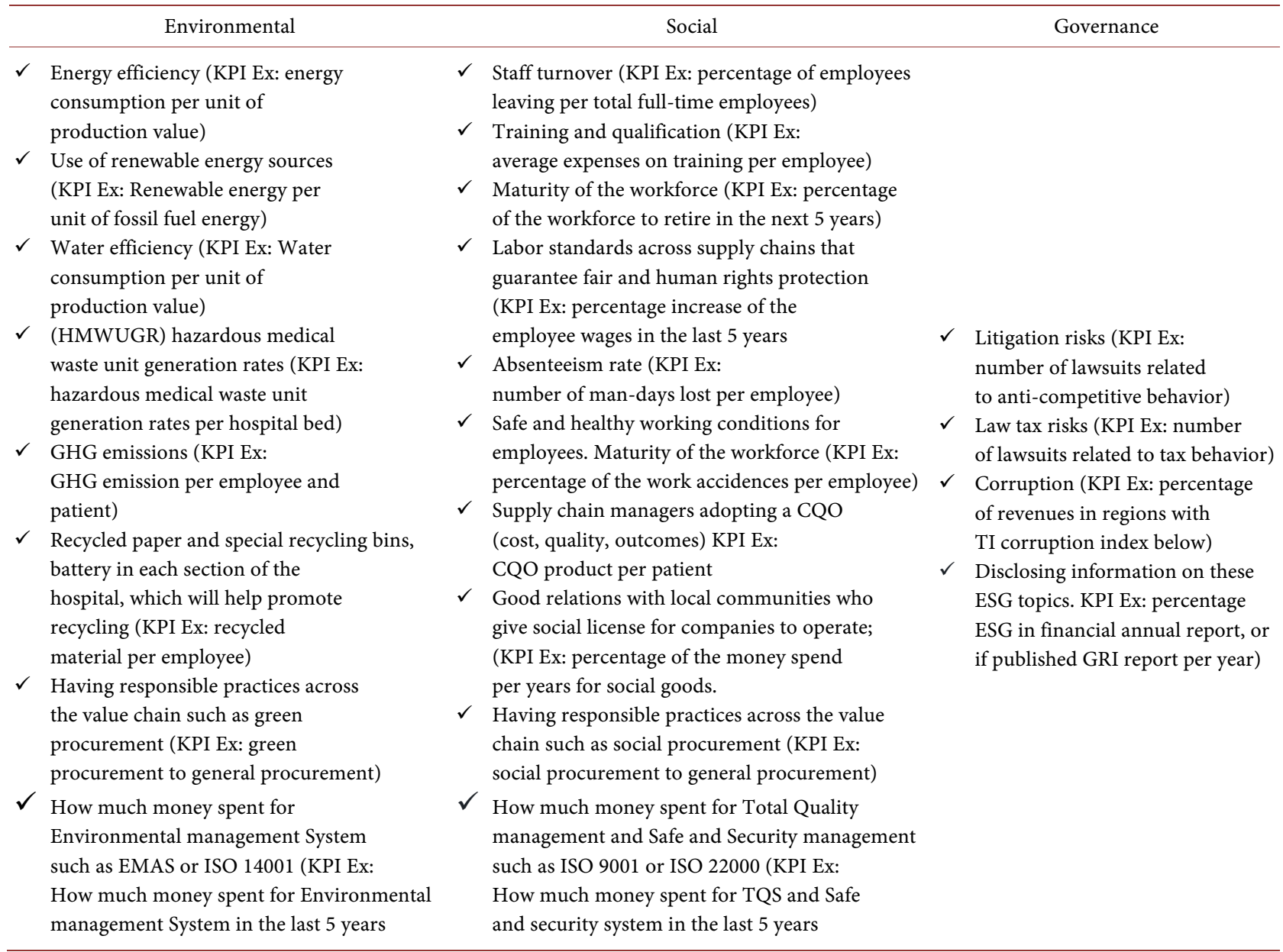

Source: own elaboration based on EFFAS and UN Principles for Responsible Investment methods for ESG and KPI Factor. 


\subsection{The ESG Index Model for Hospitals' Evaluation}

The CEOs and the shareholder management team in firms and private hospitals for the implementation of ESG management policies will not favor every public or voluntary ESG action, but only the measures that, in their best combination, increase the hospitals business value in the market, such as the optimal combination of the following indicators that have an impact on its operational management as the strategy, management, production and products service and have effect on the investment and the financial management, that factor are: [49] [50]: 1) Margin Profit Increase: Better profit margin due to higher profit and lower operating costs for hospitals through improved ESG operating capability, 2) Long term License to operate: The expectation of a constant reduction in future environmental or social costs of hospitals operation, increased profitability and better protection against unexpected environmental accidents or social and governance problems and further guarantee uninterrupted operation, 3) Promoting Good Will, Brand Name \& Reputation: Increasing the gross profit and attractiveness of health services to customers and creating new health services markets (more desirable environmental and social products and services for more stakeholders), 4) Enhancing capital investment for the development of new innovations (Capital Innovation): Development of new ESG innovations through research and hospitals development, which will provide a comparative advantage, 5) Enhancing capital investment in know-how and human skills development (Human Intellectual): Specialization and training of personnel in ESG management gives the hospital valuable human capital, 6) Ensuring stable, smooth and low interest rates (Good risk profile): Confidence in the capital market. Smaller and less systematic ESG risks and, if possible, "green" or "social" additional profit margins, bring better interest rates, premiums and easy access to money from health care providers such as banks, insurance companies, pension funds, European Union finance sustainable programs etc.

Although, there are not totally accepted ways of estimating these sustainable health care values, there are many financial methods that allow us to predict, with certain credibility, their course. Analysts, having at their disposal a variety of indexes and mathematical formulas, try to perform these estimations. In this paper I develop proposals for the use of indexes in four different organizational stages. 1) Strategy, 2) management, 3) production and products service 4) financial impact. It is suggested that ESG model is customizable in the hospitals ESG evaluation. The contents of those indexes are exhibit on the following table (Table 2) and further analyzed and developed in the following paragraphs.

In order to analyze the economic results that are designed for some decision making by the management, an indexes evaluation analysis is required, which probably affects business value. In such a case, a variety of environmental, social and corporate governance issues arises; which brings in the cost and benefit of the application of the ESG policies at the level of the firm's strategy and vision. In addition, the creation of value associated with the decrease of the 
Table 2. Organizational Stages for ESG Evaluation and their contents.

\begin{tabular}{|c|c|c|c|}
\hline (1) Strategy & (2) Management & (3) Production and Products Service & (4) Financial Impact \\
\hline $\begin{array}{l}\text { Scale of chain } \\
\text { of command }\end{array}$ & $\begin{array}{l}\text { ESG Certification (ISO. 9001, 2200, } \\
15189,45001,14001, \text { EMAS) etc. }\end{array}$ & $\begin{array}{l}\text { Measures on environmental and } \\
\text { Social impact reduction (inflow) }\end{array}$ & $\begin{array}{l}\text { Price - earnings ratio } \\
(\mathrm{P} / \mathrm{E} \text { Ratio }-\mathrm{P} / \mathrm{E})\end{array}$ \\
\hline $\begin{array}{l}\text { Range of } \\
\text { ESG policies }\end{array}$ & $\begin{array}{l}\text { Workers' participation, Staff turnover, } \\
\text { Maturity of the workforce, Absenteeism rate }\end{array}$ & $\begin{array}{l}\text { Measures on environmental and } \\
\text { Social impact reduction (outflow) }\end{array}$ & Price to Sales Index (P/S) \\
\hline Public commitment & $\begin{array}{l}\text { Position against Legislation, } \\
\text { Litigation risks and Corruption, }\end{array}$ & $\begin{array}{l}\text { Measures on environmental } \\
\text { impact reduction (waste) }\end{array}$ & Cash flow index \\
\hline \multirow[t]{3}{*}{$\begin{array}{l}\text { Commitments } \\
\text { must be published }\end{array}$} & Management of complains & $\begin{array}{l}\text { Environmental or social conditions } \\
\text { imposed on suppliers and subcontractors }\end{array}$ & $\begin{array}{l}\text { Price to Book Value Index } \\
\text { (P/B) }\end{array}$ \\
\hline & & $\begin{array}{l}\text { Measures of reduction of environmental } \\
\text { and social impact on products }\end{array}$ & Dividend estimation \\
\hline & & Advices and Services & $\begin{array}{l}\text { Evaluation of the risk factor } \\
\text { (Beta) }\end{array}$ \\
\hline
\end{tabular}

Source: own elaboration based on Sepetis et al., 2011.

environmental and social reputation can be accepted as an element of sustainable development, as far as the firm is concerned (Table 3). The main scale factors for the firm's strategy evaluation are the following:

A connection between social responsibility and environmental management and effectiveness is the risk associated with the investment for market certification, worker union and national legibility, which is determined in the financial market, and could as well be characterized as "social and environmental recognition. Even though some firm's might have applied sustainable programs of environmental or social management and have achieved a remarkable and satisfactory level of pollution reduction and social responsibility, this effort could not be totally countable on the level of decrease of systematic risk, since it is often not known to the financial market or to the investing firms and the financial analysts (Table 4). In order to evaluate the firm's management, some fundamental factors that could be used are the following:

The grade up to which the production procedures have a negative environmental or social impact or threat with severe environmental or social risks are estimated according to the firm's contribution on solving existing environmental or social problems. More particularly, the points presented on the following table (Table 5) should be taken into careful consideration in order to evaluate the production and the products of a specific hospital.

At this point, we will look through some of the most common fundamental and stock exchange indexes for financial evaluation that used from the financial stakeholders, in order to define the influence of environmental and social policy on financial performance of their, future or existing, investments. A stakeholder theory approaches this issue and analyzes the stock value in connection with the systems of environmental and social policy. This can be characterized by environmental and social effectiveness. The following table (Table 6) presents the measure for evaluating financial performance. 
Table 3. Main factors for strategy evaluation.

\begin{tabular}{|c|c|}
\hline Factors & Description \\
\hline $\begin{array}{l}\text { Scale of chain } \\
\text { of command }\end{array}$ & $\begin{array}{l}\text { The grade up to which ESG policies is being introduced to the } \\
\text { scale structure of the hospitals is assessed according to chain } \\
\text { of command that individuals in upper positions, high responsible } \\
\text { on environmental and social issues, have. }\end{array}$ \\
\hline $\begin{array}{c}\text { Range of } \\
\text { ESG policies }\end{array}$ & $\begin{array}{l}\text { The grade of ESG policies, concerning the whole range of } \\
\text { corporate activities, is estimated according to the range } \\
\text { of official Environmental and Social responsibility. }\end{array}$ \\
\hline $\begin{array}{c}\text { Public } \\
\text { commitment }\end{array}$ & $\begin{array}{l}\text { A GRI report grade up to which the company is cooperating } \\
\text { with Environmental and Social initiatives, which overcome the } \\
\text { business level, is assessed on the grounds of whether the } \\
\text { company is a member of activist or other stakeholder groups. }\end{array}$ \\
\hline $\begin{array}{l}\text { Commitments } \\
\text { must be published }\end{array}$ & $\begin{array}{l}\text { The grade up to which the public is being provided with information } \\
\text { on company's environmental social and corporate responsibly } \\
\text { responsibility is estimated according to the frequency, the range } \\
\text { and the quality of press or e-press publications. }\end{array}$ \\
\hline
\end{tabular}

Source: own elaboration based on Sepetis et al., 2011.

Table 4. Factors for management evaluation.

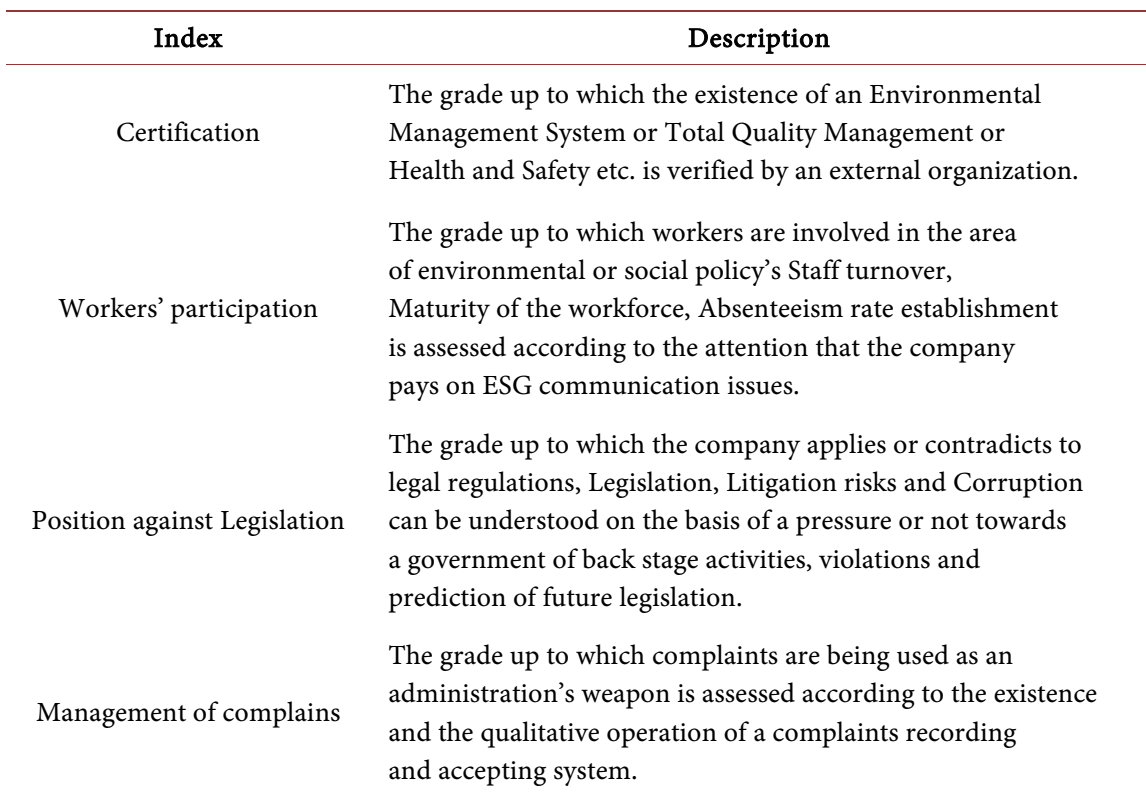

Source: own elaboration based on Sepetis et al., 2011.

Table 5. Factors for production and products service evaluation.

\begin{tabular}{cl}
\hline \multicolumn{1}{c}{ Index } & \multicolumn{1}{c}{ Description } \\
\hline $\begin{array}{c}\text { Measures on environmental } \\
\text { impact reduction (inflow) }\end{array}$ & $\begin{array}{l}\text { The grade up to which the company attempts } \\
\text { to reduce the use of energy and raw materials. }\end{array}$ \\
$\begin{array}{c}\text { Measures on environmental } \\
\text { impact reduction (outflow) }\end{array}$ & $\begin{array}{l}\text { The grade up to which the company attempts } \\
\text { to reduce the pollutant outflow. }\end{array}$ \\
$\begin{array}{c}\text { Measures on environmental } \\
\text { impact reduction (waste) }\end{array}$ & $\begin{array}{l}\text { to reduce the quantity and risk of the produced } \\
\text { waste and guarantee the use of friendly } \\
\text { methods of waste conduct. }\end{array}$ \\
\end{tabular}




\section{Continued}

Environmental or social conditions imposed on suppliers and subcontractors

Measures of reduction of environmental or social impact on products and services

Advises and Services
The grade up to which the company attempts to reduce environmental or social impact on all stages of producing procedure is estimated according to conditions imposed on suppliers and subcontractors. A sustainable purchasing policy can be used to enhance or complement other policies. In addition to cost savings and environmental or social benefits, promoting sustainability decisions for the supply chain can contribute to a positive public image.

The grade up to which the company attempts to reduce environmental or social impact on its products is estimated on the basis of adopting a planning of a product, with friendly to environment or social economy specifications, as well as on the basis of improvement of the existing, friendly to environment or social products and service.

The grade up to which the company informs its customers about the environmental aspects of products, as well as the possibilities of reduction or avoidance of negative impacts connected with the product's use and withdrawal is assessed on the grounds of the quality of information given to the customers (promotion, instructions, labels, brochures).

Source: own elaboration based on Sepetis et al., 2011.

Table 6. Financial Indexes for fundamental evaluation.

\begin{tabular}{|c|c|}
\hline Index & Description \\
\hline Price - earnings ratio (P/E Ratio - P/E) & $\begin{array}{l}\text { This index is defined as the current price's ratio } \\
\text { of a stock to the Earnings of the stock } \\
\text { during the former fiscal year. }\end{array}$ \\
\hline Price to Sales Index $(\mathrm{P} / \mathrm{S})$ & $\begin{array}{l}\text { This index is defined as the stock price's } \\
\text { ratio to sales per stock. }\end{array}$ \\
\hline Cash flow index & $\begin{array}{l}\text { The Cash flow index does not show only the cash } \\
\text { flow of a company, but it also shows how secure its } \\
\text { administration is in order to be able to face an } \\
\text { unexpected turn in funds flow. }\end{array}$ \\
\hline Price to Book Value Index (P/B) & $\begin{array}{l}\text { The Intrinsic value of a stock can be estimated if we } \\
\text { divide the whole range of funds, belong to a company, } \\
\text { with the number of its stocks in circulation. }\end{array}$ \\
\hline Dividend estimation & $\begin{array}{l}\text { The pre-mentioned reports on the } \mathrm{P} / \mathrm{E}, \mathrm{P} / \mathrm{C} \text { and } \mathrm{P} / \mathrm{S} \\
\text { constitute the most proper indexes in order for the } \\
\text { ESG to be related to the yield of financial results. }\end{array}$ \\
\hline Evaluation of the risk factor (Beta) & $\begin{array}{l}\text { Financial market will look through for new ESG } \\
\text { information which will reduce the systematic risk } \\
\text { and will form an attitude and a point of view about it. }\end{array}$ \\
\hline
\end{tabular}

Source: own elaboration based on Sepetis et al., 2011. 
The P/E ratio is considered to reveal to the investor: how much money she/he has to deposit so that she/he can acquire a certain stock title of a hospital. The development of specific ESG policies will positively affect the P/E in the way of profit margin or working capital investments, from pollution preventions. The price to $\mathrm{P} / \mathrm{S}$ index is defined as the stock price's ratio to sales per stock. The application of the ESG in the hospital will have a positive effect like product innovation and environmental label, or new environmental market risk preventions on the $\mathrm{P} / \mathrm{S}$. The cash flow index is estimated as the ratio of the credit cash to short-term obligations. It, actually, represents the capacity of the hospital to fulfill its short-term obligations. The cash flow index is influenced by the application of the ESG in the same way as the P/E index, as far as the liquid is concerned. The price to book value index $(\mathrm{P} / \mathrm{B})$ could perhaps, be considered as the most important impact of a producing process of a non-friendly to the environment or social hospitals is the environmental or social downgrading of the area. If the hospitals abandon the area, before the local authorities and the environmental or social organizations demand for the restitution of the environmental or social damage, then it will not have to face the cost and the defamation. The advice that lawyers and banks usually give is that when a hospital is found to be related to the pollution of an area, then this fact causes a significant reduction of its value. Every reduction of the price of the stock's intrinsic value gives the impression that the stock is expensive. Finally, for the valuation of the risk factor (Beta), investors believe that companies which announce new developments, related to their ESG policy, will have, in the future, a lower tendency of environmental accidents, and will adjust easier to conformity with new ESG regulations. Such a development, will, obviously have the following result: financial market will respond to the consequent reduction of prospective risk of correct ESG business activity of the hospital, which emerges through the Beta decrease.

Given the enormous amounts available through international and national social responsibility investment markets and the power of financial stakeholders seeking to influence the behavior of health care systems and hospitals, the likely outcome of such action would be at least successful. However, in the light of such profound uncertainty about the present sustainable situation, the available decision-making mechanisms are now frustrated. As a result, even in-depth analysis of the ESG challenge of the capital market and the creation of positive value in hospitals that perform environmental and social innovations, make it difficult to assess the value of the steps that may shape our long-term value. New sustainable financial analysis assessment tools for sustainable hospitals, such as those suggested in this paper with the support of reliable accounting methodologies for recording and evaluating ESG KPI factors into financial analysis statement can help to plan a well-functioning sustainable path.

\section{Conclusion}

The Brundtland definition states what would be required for sustainable development in terms of intergenerational equity: future generations shall be able to 
satisfy their needs under the same conditions as the present generation is able to do so (World Commission on Environment and Development [WCED], 1987). Therefore, in the era of economic crisis, the WHO sustainable health care system and the Goals of Sustainable Development, in order to surpass the coming decadence, hospitals need to make a total change as far as corporate philosophy is concerned, so as to demonstrate their social value awareness and environmental impact friendly policies. Moreover, health leaders have evolved the Hippocratic Oath of "First Do No Harm" beyond the immediacy of the doctor-patient relationship to incorporate a more global vision of environmental health. The article fills a gap in the literature regarding the assessment of sustainable health care management systems in terms of their sustainable finance. The initial contribution and approach presented in this paper are consisted of prioritizing the ESG index model for hospitals evaluation that has been taken into account in the decision-making process of the healthcare system managers, identifying their impact on sustainable financial systems and proposing a new approach and evaluation for comparison of healthcare systems. The main objectives of the study are to: 1) Identify the ESG factors of hospitals that are relevant for sustainable finance stakeholders, 2) Identify and provide a basic methodological approach for sustainable financial stakeholders for the evaluation of hospital ESG factors. However, the research itself is limited and is a kind of methodological theoretical proposal that can be developed in the future, with detailed data analysis on the hospital ESG factor and healthcare system. Focus is mainly on inherent limitations regarding the preliminary heterogeneous construction of the reported scores or ratings of ESG data, and sustainable financial risk of self-referencing, as well as the limited extensibility of the ESG data findings of hospitals. Future research should validate and enlarge the suggesting assessing methods, such an expansion could be in comparative empirical studies, in which sustainable financial analysis with ESG data or GRI data of hospitals could be evaluated from the capital market. In the question financing sustainable health care: who must pay and how? Liaropoulos and Goranitis answer to the question of who must pay for health care and how lies in the moral fabric and the value system of a society. It is a deeply ideological and political question with undertones of social involvement, personal responsibility, and freedom of choice [51]. In the question, is it really the best time, in times of economic crisis, for an organization and especially for a hospital to be sincerely good towards the environment and society, so that it can regain the people's trust? And also, is it a good time for financial stakeholders to invest in sustainable hospital and sustainable health care system? In order to answer that question, this study proposes a new financial analysis assessment framework to identify environmental, social and governance (ESG) issues in hospitals and the health care system with sustainable finance methods. I believe, the integration of ESG index criteria in the KPIs factors into hospital financial research and official financial analysis is an important part of identifying risks, as well as opportunities for sustainable hospitals and sustainable health care system. Today Sustainable Development Goal and Sustain- 
able Health Care have common agenda and Sustainable Finance should support the economic stabilization of health care system.

\section{Conflicts of Interest}

The author declares no conflicts of interest regarding the publication of this paper.

\section{References}

[1] OECD (2015) Healthcare Costs Unsustainable in Advanced Economies without Reform.

http://www.oecd.org/health/healthcarecostsunsustainableinadvancedeconomieswith outreform.htm

[2] UN (2015) Transforming Our World: The 2030 Agenda for Sustainable Development. Seventieth United Nations General Assembly, New York, 25 September 2015. http://www.un.org/ga/search/view doc.asp?symbol=A/RES/70/1\&Lang=E

[3] World Health Organization (2016) WHO Calls for Urgent Action to Protect Health from Climate Change-Sign the Call. World Health Organization, Geneva. http://www.who.int/globalchange/

[4] UNEP (2019) UNEP Finance Initiative's Annual Overview. https://www.unepfi.org/wordpress/wp-content/uploads/2019/09/UNEP-FI-AnnualOverview-2019-.pdf

[5] EU Commission (2018) Action Plan on Sustainable Finance. https://ec.europa.eu/info/publications/180308-action-plan-sustainable-growth en

[6] Cadman, T. (2011) Evaluating the Governance of Responsible Investment Institutions: An Environmental and Social Perspective. Journal of Sustainable Finance \& Investment, 1, 20-29.

[7] Busch, T., Bauer, R. and Orlitzky, M. (2015) Sustainable Development and Financial Markets. Business \& Society, 55, 303-329. https://doi.org/10.1177/0007650315570701

[8] Slager, R. and Chapple, W. (2015) Carrot and Stick? The Role of Financial Market Intermediaries in Corporate Social Performance. Business \& Society, 55, 398-426. https://doi.org/10.1177/0007650315575291

[9] Eurosif (2018) European SRI Study. Eurosif A.I.S.B.L., Brussels, Belgium,

[10] US SIF (2018) Foundation's Report. https://www.ussif.org/trends

[11] World Economic Forum (2019) The Global Risks Report 2019, 14th Edition. http://www3.weforum.org/docs/WEF Global Risks Report 2019.pdf

[12] Hess, J.J., Heilpern, K.L., Davis, T.E. and Frumkin, H. (2009) Climate Change and Emergency Medicine: Impacts and Opportunities. Academic Emergency Medicine, 16, 782-794. https://doi.org/10.1111/j.1553-2712.2009.00469.x

[13] Ebi, K.L., Hess, J.J. and Watkiss, P. (2017) Injury Prevention and Environmental Health. Chapter 8, Health Risks and Costs of Climate Variability and Change. 3rd Edition, The International Bank for Reconstruction and Development/The World Bank, Washington DC. https://doi.org/10.1596/978-1-4648-0522-6 ch8

[14] The Lancet (2009) Managing the Health Effects of Climate Change. The Lancet and University College London Institute for Global Health Commission. The Lancet, 373, 1693-1733.

https://www.thelancet.com/journals/lancet/article/PIIS0140-6736(09)60935-1/fullte 
$\underline{\mathrm{xt}}$

[15] Costello, A., et al. (2016) Measuring the Health-Related Sustainable Development Goals in 188 Countries: A Baseline Analysis from the Global Burden of Disease Study 2015. The Lancet, 388, 1813-1850.

[16] Stenberg, K., Hanssen, O., Tan-Torres Edejer, T., et al. (2017) Financing Transformative Health Systems towards Achievement of the Health Sustainable Development Goals: A Model for Projected Resource Needs in 67 Low-Income and Middle-Income Countries. The Lancet Global Health, 5, E875-E887. https://doi.org/10.1016/S2214-109X(17)30263-2

[17] Verguet, S., Woldemariam, A.T., Durrett, W.N., et al. (2017) Is the Sustainable Development Goal Target for Financial Risk Protection in Health Realistic? BMJ Global Health, 2, e000216. https://doi.org/10.1136/bmjgh-2016-000216

[18] Fryatt, J. and Bhuwanee, K. (2017) Financing Health Systems to Achieve the Health Sustainable Development Goals. The Lancet, 5, E841-E842. https://doi.org/10.1016/S2214-109X(17)30294-2

[19] Ling, T., Pedersen, J., Drabble, S., Celia, C. Bereton, L. and Tiefensee, C. (2012) Sustainable Development in the National Health Service (NHS). National Health Service Sustainable Development Unit.

[20] Voudrias, E.A. (2018) Healthcare Waste Management from the Point of View of Circular Economy. Waste Management, 75, 1-2.

https://doi.org/10.1016/j.wasman.2018.04.020

[21] Komilis, D., Fouki, A. and Papadopoulos, D. (2012) Hazardous Medical Waste Generation Rates of Different Categories of Health-Care Facilities. Waste Management, 32, 1434-1441. https://doi.org/10.1016/j.wasman.2012.02.015

[22] Alliance for Natural Health (2008) Sustainable Healthcare-Working towards the Paradigm Shift.

https://www.anhinternational.org/wp-content/uploads/old/files/100617-Sustainable Healthcare White-Paper.pdf

[23] Howard, J.L. (2003) Federal Commitment to Green Building: Experiences and Expectations. Office of Federal Environmental Executive (US), Washington DC, 89 p. https://archive.epa.gov/greenbuilding/web/pdf/fedcomm greenbuild.pdf

[24] Health Care With Out Harm (2011) Global Green and Healthy Hospitals a Comprehensive Environmental Health Agenda for Hospitals and Health Systems around the World.

http://greenhospitals.net/wp-content/uploads/2011/10/Global-Green-and-HealthyHospitals-Agenda.pdf

[25] Weisz, U., Haas, W., Pelikan. J.M. and Schmied, H. (2011) Sustainable Hospitals: A Socio-Ecological Approach. Gaia, 20, 191-198. https://www.oekom.de/gaia https://doi.org/10.14512/gaia.20.3.10

[26] Kolokotsa, T., Tsoutsos, T. and Papantoniou, S. (2012) Energy Conservation Techniques for Hospital Buildings. Advances in Building Energy Research, 6, 159-172. https://doi.org/10.1080/17512549.2012.672007

[27] Zamparas, M., Kapsalis, V.C., Kyriakopoulos, G.L., Aravossis, K.G., Kanteraki, A.E., Vantarakis, A. and Kalavrouziotis, I.K. (2019) Medical Waste Management and Environmental Assessment in the Rio University Hospital, Western Greece. Sustainable Chemistry and Pharmacy, 13, Article ID: 100163.

https://doi.org/10.1016/j.scp.2019.100163

[28] Environment Science Center (ESC) (2007) Greener Hospitals: Improving Environmental Performance. University Augsburg, Germany. 
[29] Hampton, T. (2012) Hospitals and Clinics Go Green for Health of Patients and Environment. The Journal of the American Medical Association, 298, 1625-1629. https://doi.org/10.1001/jama.298.14.1625

[30] World Health Organization (WHO) (2013) Health Systems: Improving Performance. World Health Organization, Geneva. http://www.who.int/whr/2000/en/whr00 en.pdf

[31] Azar, F., Farzianpour, F., Foroushani, A., Badpa, M. and Azmal, M. (2015) Evaluation of Green Hospital Dimensions in Teaching and Private Hospitals Covered by Tehran University of Medical Sciences. Journal of Service Science and Management, 8, 259-266. https://doi.org/10.4236/jssm.2015.82029

[32] Sepetis, A., Pierrakos, C. and Goula, A. (2009) Financial Assessment of Environmental Management Policies in the Operation of Hospitals. 21 st National Congress of the European Union Decision Making in Health Systems, Athens, 28-29 May 2009.

[33] World Health Organization (WHO) (2011) Health in the Green Economy: Co-Benefits to Health of Climate Change Mitigation. World Health Organization, Geneva.

[34] Porter, M.E. and Kramer, M.R. (2006) Strategy \& Society: The Link between Competitive Advantage and Corporate Social Responsibility. Harvard Business Review, 84, 78-92.

[35] Sepetis, A. (2009) Environmental and Sustainable Management in Public Health. Papazisis Publications, Athens, Greece.

[36] Weisz, U., Haas, W., Jürgen, P. and Schmied, H. (2011) Sustainable Hospitals: A Socio-Ecological Approach. Gaia, 20, 191-198. https://doi.org/10.14512/gaia.20.3.10

[37] Bouma, J.J., Jeucken, M. and Klinkers, L. (2001) Sustainable Banking the Greening of Finance. Deloitte \& Touche.

[38] Bauer, R. and Hann, D. (2014) Corporate Environmental Management and Credit Risk. EC-CE Working Paper. Maastricht University, the European Centre for Corporate Engagement, Maastricht, the Netherlands. http://ssrn.com/abstract $=1660470$

[39] U.N. F.I. (2018) Rethinking Impact to Finance the SDGs. A Position Paper and Call to Action Prepared by the Positive Impact Initiative.

https://www.unepfi.org/wordpress/wp-content/uploads/2018/11/Rethinking-Impact -to-Finance-the-SDGs.pdf

[40] Sepetis, A. and Rizos, F. (2010) The Implementation of Environmental and Social Policy in Greek Health Units and Evaluation It through the Global Reporting Initiative's (GRI) Report. International Conference, Protection and Restoration of the Environment, 5-9 July 2010.

[41] Chatterji, A.K., Levine, D.I. and Toffel, M.W. (2009) How Well Do Social Ratings Actually Measure Corporate Social Responsibility? Journal of Economics \& Management Strategy, 18, 125-169. https://doi.org/10.1111/j.1530-9134.2009.00210.x

[42] Orlitzky, M. (2013) Corporate Social Responsibility, Noise, and Stock Market Volatility. Academy of Management Perspectives, 27, 238-254. https://doi.org/10.5465/amp.2012.0097

[43] Shapiro, K., et al. (2000) Healthy Hospitals: Environmental Improvements through Environmental Accounting' Tellus Institute Resource and Environmental Strategies. US Environmental Protection Agency Office of Prevention, Pesticides and Toxic Substances.

[44] Sepetis, A. and Kada, E. (2009) Environmental and Sustainable Accounting as a Key 
Indicator for the Environmental Efficiency of Hospital. 11th International Conference on Environmental Science and Technology, Chania, Greece, 3-5 September 2009.

[45] Sustainability Accounting Standards Board (2013) Health Care Delivery Research Brief.

https://www.sasb.org/wp-content/uploads/2019/08/SASB-Health-Care-Delivery-Ind ustry-Brief.pdf

[46] Senay, E. and Landrigan, P.J. (2018) Assessment of Environmental Sustainability and Corporate Social Responsibility Reporting by Large Health Care Organizations. The Journal of the American Medical Association, 1, e180975.

https://doi.org/10.1001/jamanetworkopen.2018.0975

[47] European Federation of Financial Analysts Societies (EFFAS) (2014) KPIs for ESG: A Guideline for the Integration of ESG into Financial Analysis and Corporate Valuation.

https://www.dvfa.de/fileadmin/downloads/Publikationen/Standards/KPIs for ESG 3 0 Final.pdf

[48] U.N. Principles for Responsible Investment (PRI) (2018) Impact Investing Market Map. United Nations, New York. https://www.unpri.org/download?ac=5426

[49] Epstein, M.J. (2008) Introduction: Improving Social and Financial Performance in Global Corporations. In: Making Sustainability Work. Best Practices in Managing and Measuring Corporate Social, Environmental and Economic Impacts, Taylor \& Francis Group, Philadelphia, PA, 19-32. https://doi.org/10.4324/9781351280129-1

[50] Schaltegger, S., Lüdeke-Freund, F. and Hansen, E.G. (2012) Business Cases for Sustainability the Role of Business Model Innovation for Corporate Sustainability. International Journal of Innovation and Sustainable Development, 6, 95-119. https://doi.org/10.1504/IJISD.2012.046944

[51] Liaropoulos, L. and Goranitis, I. (2015) Health Care Financing and the Sustainability of Health Systems. International Journal for Equity in Health, 14, 80. https://doi.org/10.1186/s12939-015-0208-5 